\title{
Cập nhật hội chứng đáp ứng siêu viêm ở trẻ em phối hợp với nhiễm COVID-19
}

\author{
Đào Minh Tuấn ${ }^{1}$
}

\begin{abstract}
Bệnh viện Nhi Trung uoong, 18/879 La Thành, Đống Đa, Hà Nội, Việt Nam
\end{abstract}
Đại dịch COVID-19 ban đầu chỉ gây ra bệnh nhẹ đối với trẻ em, hơn nữa tỷ lệ mắc COVID-19 ở trẻ em cũng rất thấp. Tuy nhiên gần đây, nhất là sau khi xuất hiện những biến thể mới của virus COVID-19, số lượng trẻ em nhiễm virus này có xu hướng tăng lên. Điều quan tâm hơn là biểu hiện phản ứng siêu viêm của trẻ cũng mạnh và đa dạng, phức tạp hơn tổn thương ở phổi cũng nặng và tiên lượng xấu hơn.

Hội chứng viêm đa hệ liên quan tạm thời với SARS-CoV-2 được nghiên cứu ở nhiều trung tâm.

Đặc điểm lâm sàng của tình trạng viêm nhiễm cơ quan bao gồm sốt dai dẳng với các bằng chứng siêu viêm và rối loạn chức năng đơn hoặc đa cơ quan trong trường hợp không có các bệnh nhiễm trùng khác đồng thời. Một số trẻ có thể biểu hiện viêm giống bệnh Kawasaki, hội chứng sốc nhiễm độc hoặc hội chứng bão cytokine. Bệnh nhi diễn biến xấu đi nhanh, cần có biện pháp hỗ trợ đặc biệt hoặc cấp cứu ở các trung tâm hồi sức.

Các xét nghiệm ban đầu tỷ lệ phát hiện SARS-CoV-2 thường thấp (PCR), sau khi lâm sàng đột ngột nặng lên, phản ứng viêm rầm rộ mới phát hiện được virus. Tuy nhiên đa số trẻ có kháng thể đối với SARS-CoV-2, nhưng ở mắc nồng độ kháng thể thấp.

\footnotetext{
* Tác giả liên hệ

E-mail address: daominhtuan@rich.org.vn

https://doi.org/10.47973/jprp.v5i4.329
}

Đa số nghiên cứu cho thấy: mặc dù cơ chế bệnh sinh còn chưa rõ ràng, song những tổn thương đặc biệt ở phổi trẻ liên quan trực tiếp đến con đường trung gian miễn dịch với hội chứng kích hoạt đại thực bào, hội chứng viêm đa hệ, cơn bão giải phóng cytokine...trong bệnh cảnh nhiễm SARS-CoV-2.

Trong mộtnghiên cứu của Tristan Ramcharan mô tả hội chứng viêm đa hệ ở trẻ em liên quan đến thời gian với SARS-CoV-2 (PIMS-TS) gây ra biểu hiện trùng lặp với bệnh Kawasaki và hội chứng sốc nhiễm độc, lâm sàng có dấu hiệu viêm cơ tim nặng hơn (CRP, ferritin, troponinI, $\mathrm{CK}$ và pro-BNP, hở van tim thoáng qua, phân suất tống máu thất trái giảm, bất thường ở động mạch vành) [1].

Ngoài các biểu hiện ở tim, phổi, dấu hiệu của trẻ nhiễm SARS-CoV-2 còn là nôn (45\%), đau bụng (53\%), tiêu chảy (52\%), phát ban (58\%), viêm kết mạc (44\%) [3].

Như vậy PIMS-TS/MIS (-C) là một bệnh nặng, không đồng nhất, phong phú về dịch tễ học, tuy nhiên tỷ lệ tử vong thấp. Cho đến nay các đồng thuận về nghiên cứu cho thấy phản ứng siêu viêm liên quan cơ chế miễn dịch học trong đa số trẻ em nhiễm virus SARS-CoV-2.

Tác giả Christian $\mathrm{A}$ Rostad và cộng sự đã nghiên cứu giảm phản ứng huyết thanh của hội chứng hô hấp cấp tính nghiêm trọng của trẻ nhiễm SARS-CoV-2, vào viện với hội chứng viêm đa hệ (MIS-C). Kết quả cho thấy hiệu giá kháng thể SARS-CoV2 IgG tăng đột biến, song song nồng độ kháng thể Protein Nucleocapsid 
cũng tăng cao. Ngoài ra kháng thể RBG IgM xuất hiện. Như vậy vai trò của $\operatorname{IgG}$, IgM giúp chẩn đoán nhiễm SARS-CoV-2 và gián tiếp biểu hiện tình trạng phản ứng viêm đa hệ (MIS-C) [5].

\section{Tài liệu tham khảo}

[1] ChandrikaSB,LatikaG,Balasubramanian $\mathrm{S}$ et al. Hyperinflammtory syndrome in children associated with COVID-19: Need for awarences. Indian Pediatr 2020;57(10):929-935. https://doi. org/10.1007/s13312-020-1997-1.

[2] Tristan R, Oscar N, Chui YL et al. Paediatric inflammatory multisystem syndrome: Temporally associated with SARS-CoV-2 (PIMS-TS): Cardiac features, management and short-term outcomes at a UK Tertiary Paediatric Hospital. Pediatr Cardiol
2020;41(7):1391-1401. https://doi. org/10.1007/s00246-020-02391-2.

[3] Elizabeth W, Alasdair B, Julia K et al. Clinical characteristics of 58 children with a pediatric inflammatory multisystem syndrome temporally associated with SARS-CoV-2. JAMA 2020;324(3):259-269. https://doi. org/10.1001/jama.2020.10369.

[4] Levi H, Ruben VP, Filomeen H. Multisystem inflammatory syndrome in children to COVID-19: a systematic review. Eur J Pediatr 2021 Feb 18:1-16. https://doi.org/10.1007/s00431-02103993-5

[5] Christian AR, Ann C, Grace M et al. Quantitative SARS-CoV-2 serology in children with multisystem inflammatory sysdrome (MIS-C). Pediatrics 2020, 146 (6) e2020018242. https://doi. org/10.1542/peds.2020-018242. 